\title{
Causation in Rule 10b-5 Actions For Corporate Mismanagement
}

Rule 10b-5 ${ }^{1}$ of the Securities Exchange Act of $1934^{2}$ has been likened to the medieval alchemist's "universal solvent" that was so potent that it dissolved every container devised to hold it. ${ }^{3}$ Nonetheless, in recent years the Supreme Court has attempted repeatedly to limit the application of the rule.4 In Santa Fe Industries, Inc. v. Green, ${ }^{5}$ the Court held that mere unfairness or breach of fiduciary duty, unsupported by allegations of deception or manipu-

117 C.F.R. § $240.10 \mathrm{~b}-5$ (1981). The rule states:

It shall be unlawful for any person, directly or indirectly, by the use of any means or instrumentality of interstate commerce, or of the mails or of any facility of any national securities exchange,

(a) To employ any device, scheme, or artifice to defraud,

(b) To make any untrue statement of a material fact or to omit to state a material fact necessary in order to make the statements made, in the light of the circumstances under which they were made, not misleading, or

(c) To engage in any act, practice, or course of business which operates or would operate as a fraud or deceit upon any person, in connection with the purchase or sale of any security.

The rule was promulgated by the Securities and Exchange Commission in 1942 under section 10(b) of the Securities Exchange Act of 1934, 15 U.S.C. $₹ 78 \mathrm{j}(\mathrm{b})(1976)$, which reads as follows:

It shall be unlawful for any person, directly or indirectly, by the use of any means or instrumentality of interstate commerce or of the mails, or of any facility of any national securities exchange ....

(b) To use or employ, in connection with the purchase or sale of any security registered on a national securities exchange or any security not so registered, any manipulative or deceptive device or contrivance in contravention of such rules and regulations as the Commission may prescribe as necessary or appropriate in the public interest or for the protection of investors.

215 U.S.C. $\$ \S 78 \mathrm{a}-78 \mathrm{kk}$ (1976).

${ }^{3}$ Kaplan, Fiduciary Responsibility in the Management of the Corporation, 31 Bus. LAw. 883, 895-96 (1976). For general commentary on the rule, see A. Bromberg \& L. Lowenfels, Securities Fraud \& Commodities Fraud (1979).

- The Supreme Court has held that proof of an actual purchase or sale of securities, rather than a lost opportunity to purchase, is necessary to recover for a violation of rule 10b-5, Blue Chip Stamps v. Manor Drug Stores, 421 U.S. 723, 754-55 (1975), and that scienter, not mere negligence, is necessary to establish a $10 \mathrm{~b}-5$ violation, Ernst \& Ernst v. Hochfelder, 425 U.S. 185, 201 (1976). See also Lowenfels, Recent Supreme Court Decisions Under the Federal Securities Laws: The Pendulum Swings, 65 Geo. L.J. 891 (1977).

s 430 U.S. 462 (1977). 
lation, is not actionable under rule $10 \mathrm{~b}-5 .^{6}$ This holding, although restrictive, did not succeed in placing every breach of fiduciary duty beyond the compass of the rule. In Goldberg v. Meridor, ${ }^{7}$ the Second Circuit subsequently held that nondisclosure of a breach of fiduciary duty itself constitutes a violation of rule $10 \mathrm{~b}-5$, if the otherwise powerless shareholders could have sought to enjoin the alleged breach under state law, had full disclosure been made. ${ }^{8}$

The difficulties inherent in the Goldberg court's reference to state remedies have only begun to be examined. ${ }^{\circ}$ Courts considering the question have agreed with Goldberg that in certain cases of corporate mismanagement, a 10b-5 claim is stated if shareholders have been denied the opportunity to pursue state injunctive remedies by the defendant's failure to disclose. ${ }^{10}$ The courts are di-

- Id. at 471-74.

7567 F.2d 209 (2d Cir. 1977), cert. denied, 434 U.S. 1069 (1978).

- The commentators are divided as to whether Goldberg eviscerates Santa Fe. See Note, Goldberg v. Meridor: The Second Circuit's Resurrection of Rule 10b-5 Liability for Breaches of Corporate Fiduciary Duties to Minority Shareholders, 64 VA. L. REv. 765 (1978) [hereinafter cited as Virginia Note] (arguing that Goldberg reopened the doors of federal courts to matters Santa Fe had relegated to state courts). Accord, Campbell, Santa Fe. Industries, Inc. v. Green: An Analysis Two Years Later, 30 MarNe L. Rev. 187, 192 (1979). But see Note, Suits for Breach of Fiduciary Duty Under Rule 10b-5 After Santa Fe Industries, Inc. v. Green, 91 HARv. L. REv. 1874 (1978) [hereinafter cited as Harvard Note] (arguing that Goldberg is consistent with Santa Fe).

- See, e.g., Kerrigan v. Merrill Lynch, Pierce, Fenner \& Smith, Inc., 450 F. Supp. 639, 644 (S.D.N.Y. 1978).

10 IIT v. Cornfeld, 619 F.2d 909, 922-23 (2d Cir. 1980); Healey v. Catalyst Recovery, Inc., 616 F.2d 641, 647 (3d Cir. 1980); Alabama Farm Bureau Mut. Cas. Co. v. American Fidelity Life Ins. Co., 606 F.2d 602, 614 (5th Cir. 1979), cert. denied, 449 U.S. 820 (1980); Kidwell ex rel. Penfold v. Meikle, 597 F.2d 1273, 1292 (9th Cir. 1979); Wright v. Heizer Corp., 560 F.2d 236, 250 (7th Cir. 1977), cert. denied, 434 U.S. 1066 (1978); SEC v. Parkland Hosiery Co., 558 F.2d 1083, 1088 (2d Cir. 1977); Dower v. Mosser Indus., Inc., 488 F. Supp. 1328, 1333-34 (E.D. Pa. 1980); Jacobs v. Hanson, 464 F. Supp. 777, 780-81 (D. Del. 1979).

It has been suggested that this unanimity of opinion lacks sufficient justification. Judge Aldisert, dissenting in Healey v. Catalyst Recovery, Inc., 616 F.2d 641, 651 (3d Cir. 1980), argued that Goldberg improperly extends the reach of rule $10 \mathrm{~b}-5$. He reasoned that, by implying a cause of action in favor of a shareholder who was deprived of the opportunity to file a state suit, Goldberg changes the emphasis of rule $10 \mathrm{~b}-5$ from protection of the "reasonable investor" to protection of "a certain type of litigant." 616 F.2d at 654. Accord, Virginia Note, supra note 8 , at 777.

Ample precedent supports the view that the federal securities laws were intended to protect only investment decisions-that is, decisions to purchase or sell securities. The prevailing materiality standard announced by the Supreme Court in TSC Indus., Inc. v. Northway, Inc., 426 U.S. 438,449 (1976), emphasizes the significance of information to the "reasonable investor." Similarly, just as materiality under rule 14a-9, 17 C.F.R. $\$ 240.14 a-9$ (1981), which regulates disclosures in proxy solicitations, concentrates on the effect the information would have had on the investor's vote, materiality under rule $10 \mathrm{~b}-5$, which proscribes fraud "in connection with the purchase or sale of any security," see note 1 supra, 
vided, however, over what showing of success in the hypothetical state court action the derivative plaintiff must make to obtain relief under rule 10b-5. The tests developed by the courts of appeals include a showing of the mere existence of a state remedy, ${ }^{11}$ a showing of a prima facie case for the state remedy,,$^{12}$ a showing of a reasonable probability of ultimate success in the state action, ${ }^{13}$ and a showing that the state action would have succeeded. ${ }^{14}$

After reviewing the factual and legal bases of the Goldberg rationale, this comment distinguishes between the typical 10b-5 case in which the plaintiff has an investment decision to make, and cases such as Goldberg and its progeny, in which the plaintiff has a litigation decision to make. It argues that the relationship between

should focus on information affecting the investor's decision to purchase or sell his securities. See, e.g., O'Brien v. Continental Ill. Nat'l Bank \& Trust Co., 593 F.2d 54, 60 (7th Cir. 1979).

It also can be argued that Goldberg, by implying a federal cause of action where state law relief is available, stands part IV of Santa $F e$ on its head: it provides federal relief to plaintiffs who have state remedies and denies federal relief to plaintiffs without state remedies. Virginia Note, supra note 8, at 775-76. Such a regimen of federal protection makes the imposition of federal liability dependent upon the venue in which the rule $10 \mathrm{~b}-5$ action is brought. Ironically, it also may make the minority shareholder more vulnerable to overreaching by corporate fiduciaries, for it removes whatever impetus Santa $\mathrm{Fe}$ may have created for greater state court protection in this area.

It must be noted, however, that from a purely economic perspective there may be no principled distinction between an "investment decision" and the "litigation decision" that forms the basis for implying a federal cause of action in Goldberg and its progeny. In either case, the economic consequences of a consummated decision-be it to buy or sell securities, vote a proxy, or secure injunctive relief under state law-will be an increase or diminution in the value of the shareholder's equity interest. Consequently, the decision to seek state injunctive relief may be as much an "investment decision" as is the decision to vote a proxy or purchase a security.

11 Goldberg v. Meridor, 567 F.2d 209 (2d Cir. 1977), cert. denied, 434 U.S. 1069 (1978).

12 Alabama Farm Bureau Mut. Cas. Co. v. American Fidelity Life Ins. Co., 606 F.2d 602 (5th Cir. 1979), cert. denied, 449 U.S. 820 (1980).

13 Healey v. Catalyst Recovery, Inc., 616 F.2d 641 (3d Cir. 1980).

${ }^{14}$ Kidwell ex rel. Penfold v. Meikle, 597 F.2d 1273 (9th Cir. 1979). See also Wright v. Heizer Corp., 560 F.2d 236 (7th Cir. 1977), cert. denied, 434 U.S. 1066 (1978). The decision in Wright has been interpreted differently by the commentators. Compare Harvard Note, supra note 8, at $1893 \mathrm{n} .109$ (arguing that Wright implied there would be no liability absent a showing of success in the state action) and Comment, A Post Santa Fe Blueprint for Courts in Rule 10b-5 Actions for Breach of Fiduciary Duty: Kidwell v. Meikle, 14 U. RicH. L. REv. 585, 602 (1980) [hereinafter cited as Richmond Note], with Note, Securities Law-Rule 10b-5-Deception and Materiality Requirements in Corporate Mismanagement Cases, 66 Geo. L.J. 1593, 1610 n.105 (1978) (suggesting that Wright implied that proof of the availability of a state cause of action was sufficient to establish $10 \mathrm{~b}-5$ liability). The Seventh Circuit in fact concluded that the plaintiff would have succeeded in state court, but did not reach the question whether proof of success was essential to the rule $10 \mathrm{~b}-5$ claim. 560 F.2d at 250-51. 
the defendant's violation and the plaintiff's injury is attenuated in the litigation decision case. Consequently, in an action premised on Goldberg, some showing that the state action would have been successful is necessary to establish the causal connection between violation and injury required for rule 10b-5 liability. The comment concludes that a prima facie showing of success for state injunctive relief is the optimum standard, for it is rigorous enough to satisfy the federal interest in deterring vexatious suits and ensuring full disclosure, yet liberal enough to avoid a trial of the state claim in federal court, thus preserving the traditional state interest in the development of corporation law.

\section{Rule 10b-5 and Mismanagement by Corporate Fiduciaries}

\section{A. Patterns of Deception}

A plaintiff in a private action for damages under rule $10 \mathrm{~b}-5^{15}$ must prove that in connection with the purchase or sale of securities, ${ }^{16}$ the defendant knowingly ${ }^{17}$ made a material misrepresentation or omission ${ }^{18}$ that induced the plaintiff to act, or refrain from acting, to his detriment. ${ }^{19}$ The violation is the deceptive misrepresentation or omission of material facts, and the injury is the economic loss precipitated by an investment decision to purchase or sell securities. The locus of that decision may vary from case to case. Because a $10 \mathrm{~b}-5$ action requires a causal connection between violation and injury, ${ }^{20}$ the typical case is one in which the plaintiff makes the investment decision that leads to his loss. ${ }^{21}$ Such cases

${ }^{15}$ An implied private right of action under rule 10b-5 first was recognized in Kardon v. National Gypsum Co., 73 F. Supp. 798 (E.D. Pa. 1947), and was expressly approved by the Supreme Court in Superintendent of Ins. v. Bankers Life \& Cas. Co., 404 U.S. 6, 13 n.9 (1971).

16 Blue Chip Stamps v. Manor Drug Stores, 421 U.S. 723, $731-55$ (1975).

17 Ernst \& Ernst v. Hochfelder, 425 U.S. 185, 194-214 (1976).

18 17 C.F.R. $\$ 240.10 b-5$ (1980).

10 In defining the elements of a rule $10 \mathrm{~b}-5$ cause of action, the courts have borrowed heavily from the common law tort action for deceit. See Blue Chip Stamps v. Manor Drug Stores, 421 U.S. 723, 744 (1975); 3 L. Loss, Securities Regulation 1430-44 (2d ed. 1961). The basic elements of that action are (1) a false representation of fact made by the defendant; (2) knowledge or scienter on the part of the defendant that the representation is false; (3) an intention to induce the plaintiff to act or refrain from action in reliance upon the misrepresentation; (4) justifiable reliance upon the representation on the part of the plaintiff in taking action or refraining from it; and (5) damage to the plaintiff resulting from such reliance. W. Prosser, The LAW OF TorTs $\$ 105$ (4th ed. 1971).

${ }^{20}$ Shapiro v. Merrill Lynch, Pierce, Fenner \& Smith, Inc., 495 F.2d 228, 238 (2d Cir. 1974).

${ }^{21}$ Klamberg v. Roth, 473 F. Supp. 544, 550 (S.D.N.Y. 1979). 
include insider trading based on undisclosed material information, ${ }^{22}$ trading prompted by misleading corporate publicity, ${ }^{23}$ and broker-dealer misconduct. ${ }^{24}$ The complaint in such cases is that the defendant's deceptive conduct induced the plaintiff to purchase or sell securities to his detriment. Rule $10 \mathrm{~b}-5$ operates in these circumstances to preserve the free market by proscribing activities that impede the flow of information between the parties to a securities transaction. ${ }^{25}$

Rule $10 \mathrm{~b}-5$ also has been invoked in cases of corporate mismanagement. ${ }^{26}$ These cases generally involve three parties. The complaint is that an insider or controlling shareholder has caused the corporation to execute a transaction ${ }^{27}$ that results in economic injury to the independent shareholder. ${ }^{28}$ Because it is the corporation that has bought or sold the securities, the plaintiff in the 10b5 suit for mismanagement is generally the corporate entity, represented derivatively by the independent shareholders; the defendants are the directors or controlling shareholders responsible for the challenged transaction. ${ }^{29}$ Unlike the typical 10b-5 case, the plaintiff in corporate mismanagement cases is not the investment decision maker. Rather, the decision to purchase or sell securities is made by officers or directors, most or all of whom are interested in the transaction. Alternatively, although shareholder input may be solicited through a proxy vote, the minority is powerless because the control group has sufficient strength to approve the

22 See, e.g., SEC v. Texas Gulf Sulphur Co., 401 F.2d 883, 845-50 (2d Cir. 1968), cert. denied, 394 U.S. 976 (1969); Speed v. Transamerica Corp., 99 F. Supp. 808 (D. Del. 1951).

${ }^{23}$ See, e.g., Heit v. Weitzen, 402 F.2d 909 (2d Cir. 1968) (annual report), cert. denied, 395 U.S. 903 (1969); SEC v. Texas Gulf Sulphur Co., 401 F.2d 833, 862-64 (2d Cir. 1968) (press release), cert. denied, 394 U.S. 976 (1969).

${ }^{24}$ See, e.g., Goodman v. H. Hentz \& Co., 265 F. Supp. 440 (N.D. IIl. 1967) (selling fictitious securities); First Anchorage Corp., 34 S.E.C. 299 (1952) (false confirmation of transaction); Behel, Johnson \& Co., 26 S.E.C. 163 (1947) (churning).

${ }^{25}$ Healey v. Catalyst Recovery, Inc., 616 F.2d 641, 645-46 (3d Cir. 1980); Hundahl v. United Benefit Life Ins. Co., 465 F. Supp. 1349, 1360-64 (N.D. Tex. 1979).

${ }^{28} 4$ L. Loss, supra note 19, at 3631 (2d ed. Supp. 1969); Sherrard, Federal Judicial and Regulatory Responses to Santa Fe Industries, Inc. v. Green, 35 WASH. \& LEE L. REv. 695, 698 (1978). Alternative terms applied to these cases include "breach of fiduciary duty" or "conflict of interest transactions." See 1 A. BROMBERg \& L. LowENFELs, supra note 3, $\S 4.7(000)(1)$. Conflict of interest transactions are defined as those to which the company is a party. By definition, some of the people acting for or controlling the company are also personally interested in the transaction, depriving it of an arms-length character. Id.

${ }^{27}$ Transactions such as short-form mergers or purchases or sales of treasury stock are typical.

${ }^{28} 1$ A. BRomberg \& L. Lowenfels, supra note $3, \S 4.7(541)$.

${ }^{29}$ Id. $\S 4.7(000)(1)$. 
transaction. ${ }^{30}$ Deprived of an "investment decision," the independent shareholder may be able to make a "litigation decision":31 in some states, he can seek to enjoin the transaction under state law for breach of fiduciary duty.

\section{B. Santa Fe}

Santa Fe Industries, Inc. v. Green ${ }^{32}$ was a case of alleged corporate mismanagement involving a subsidiary, a controlling parent corporation, and minority shareholders of the subsidiary. Minority shareholders of Kirby Lumber Corp., the subsidiary, brought a derivative 10b-5 action on behalf of Kirby against Santa Fe Industries, Inc., a 96 percent controlling shareholder of Kirby that had completed a short-form merger of the two corporations under Delaware law. ${ }^{33}$ The complaint alleged that the terms of the merger were unfair but conceded that the majority had made no material

so Id. $\S 4.7(551)(2)$. One of the difficulties in cases of corporate mismanagement under rule $10 \mathrm{~b}-5$ arises in determining who is deceived if the real decision makers (the interested directors or control persons) are fully apprised of all the facts. This difficulty was responsible in part for the courts' initial refusal to apply rule 10b-5 to claims of corporate mismanagement. See Birnbaum v. Newport Steel Corp., 193 F.2d 461 (2d Cir.), cert. denied, 343 U.S. 956 (1952). Subsequently, courts managed to avoid the issue of deception entirely by holding defendant-insiders liable under the rule merely because they exerted a "controlling influence" on a corporate transaction to the detriment of the independent shareholders. This controlling influence test first was articulated in Schoenbaum v. Firstbrook, 405 F.2d 215, 219-20 (2d Cir. 1968) (en banc), cert. denied, 395 U.S. 906 (1969), and subsequently was adopted by other circuits. See, e.g., Travis v. Anthes Imperial, Ltd., 473 F.2d 515 (8th Cir. 1973); Shell v. Hensley, 430 F.2d 819 (5th Cir. 1970); Swanson v. American Consumer Indus., Inc., 415 F.2d 1326 (7th Cir. 1969). The controlling influence test was characterized as the "new fraud" because it established a separate ground-unfairness plus control-for rule 10b-5 liability. See Bloomenthal, From Birnbaum to Schoenbaum: The Exchange Act and Self-Aggrandizement, 15 N.Y.L.F. 332, 346-48 (1969); Comment, Schoenbaum v. Firstbrook: The "New Fraud" Expands Federal Corporation Law, 55 VA. L. REv. 1103, 1111-16 (1969). This "new fraud," sounding in breach of fiduciary duty rather than deception, did not survive Santa Fe. Goldberg v. Meridor, 567 F.2d 209, 217 (2d Cir. 1977), cert. denied, 434 U.S. 1069 (1978). Consequently, in Goldberg $v$. Meridor, Judge Friendly developed the theory of "constructive deception." See text and note at note 44 infra.

31 The terms "investment decision" and "litigation decision" are used in this comment for descriptive purposes. It has been argued, however, that as a matter of law Goldberg impermissibly extends rule 10b-5 to "litigation decisions." See note 10 supra.

32430 U.S. 462 (1977).

${ }^{33}$ Des. Code ANN. tit. 8, $\S 253(a)$ (1974), permits a parent corporation owning at least 90 percent of the stock of a subsidiary to merge with that subsidiary upon approval by the parent's board of directors. The statute authorizes the parent to make cash payment for the shares of the minority stockholders, but does not require the consent of the minority stockholders. However, any stockholder who is dissatisfied with the terms of the merger may petition the Delaware Court of Chancery for an appraisal of the fair value of his shares. Id. $\S \S 253,262$ (1974 \& Supp. 1980). 
omissions or misstatements. ${ }^{34}$ The Supreme Court found no basis for a federal claim, holding that mere unfairness or breach of fiduciary duty, without allegations of deceptive or manipulative conduct, are not cognizable under section $10 \mathrm{~b}$ or rule $10 \mathrm{~b}-5 .^{35}$ The Court further observed in footnote 14 that, even if there had been deception in the majority's failure to give the Kirby shareholders advance notice of the merger, ${ }^{36}$ such deception was not material because the derivative plaintiffs did "not indicate how they might have acted differently had they had prior notice. . . . [T] [Tey could not have enjoined the merger because an appraisal proceeding is their sole remedy in the Delaware courts for any alleged unfairness in the terms of the merger." ${ }^{\text {"37 }}$ In the absence of a state remedy for enjoining the merger, the minority shareholders were powerless to affect the transaction. The Court's holding of immateriality followed from the principle that information is not material to those powerless to act on it. ${ }^{38}$

In part IV of its opinion, the Court offered an alternative ground for its decision, stating that a private cause of action should not be implied because it would not further the policies embodied in the Securities Exchange Act and would trench on areas traditionally relegated to state law. ${ }^{38}$ The Court reasoned that the fundamental purpose of the Act is not to ensure fairness, but to implement a policy of "full disclosure." The gravamen of the complaint was that the transaction was unfair; therefore, the Court re-

34 430 U.S. at 474.

${ }^{35}$ Id. at 477 .

s6 The Delaware Corporation Code does not require advance notice. Rather, it requires only that notice of the merger be given within 10 days after its effective date. DEL. CoDe ANN. tit. 8, § 253 (1974). Nevertheless, plaintiffs argued that defendants' failure to give advance notice constituted "deception" within the meaning of rule 10b-5. 430 U.S. at 467.

${ }^{37} 430$ U.S. at 474 n.14.

${ }^{38}$ R. Jennings \& H. Marsh, Securities Regulation 954 n.41 (4th ed. 1977). Compare St. Louis Union Trust Co. v. Merrill Lynch, Pierce, Fenner \& Smith, 562 F.2d 1040 (8th Cir. 1977), cert. denied, 435 U.S. 925 (1978) and Ryan v. J. Walter Thompson, 453 F.2d 444 (2d Cir. 1971) (failure to disclose that corporation was going public prior to corporation's exercise of its option to purchase plaintiff's stock not material because plaintiff was legally obligated to sell regardless of what he knew), cert. denied, 406 U.S. 907 (1972) with Ayres v. Merrill Lynch, Pierce, Fenner \& Smith, 538 F.2d 532 (3d Cir.) (although firm could repurchase employee's stock within 90 days after he retired, information about "going public" was material to employee's decision as to date of retirement), cert. denied, 429 U.S. 1010 (1976).

${ }^{39} 430$ U.S. at 478-79. Justices Stevens and Blackmun did not concur in part $I V$ of the majority opinion, considering it unnecessary to the decision, $i d$. at $480-81$, and Justice Brennan dissented for the reasons stated in the majority and concurring opinions in the court of appeals. Id. at 480 . 
fused to recognize a claim that served a "subsidiary purpose" of the statute. ${ }^{.0}$ The Court also suggested that permitting such a claim would invite both vexatious litigation from a widely expanded class of plaintiffs and concomitant federal interference with state corporation law. ${ }^{41}$

\section{Goldberg}

The Supreme Court's decision in Santa Fe, although restrictive, has not automatically insulated every breach by corporate fiduciaries from the reach of rule 10b-5. In Goldberg v. Meridor, ${ }^{42}$ the Second Circuit held that nondisclosure or misleading disclosure of a breach of fiduciary duty constitutes a violation of the rule, if after full disclosure derivative shareholders could have sought state injunctive relief against the breach.

Goldberg was a derivative $10 \mathrm{~b}-5$ action brought by minority shareholders of Universal Gas \& Oil Company, Inc., charging that Universal's controlling parent had caused it to purchase shares in the parent for grossly inadequate consideration. ${ }^{43}$ Although Universal's entire board of directors was fully informed and the shareholders had no investment decision to make, the Second Circuit, with Judge Friendly writing for the court, held that the corporate entity was deceived because the independent shareholders of Universal were "lulled into security" by the defendants' failure to disclose their conflict of interest and the true value of the consideration received." To test the materiality of these undisclosed facts,

10 Id. at $477-78$.

41 Id. at 479.

4567 F.2d 209 (2d Cir. 1977), cert. denied, 434 U.S. 1069 (1978).

43 The transaction provided for the issuance to the parent, Maritimecor, S.A., of 4.2 million shares of Universal stock in exchange for all of Maritimecor's assets and Universal's assumption of Maritimecor's liabilities. The transaction allegedly caused the dissipation of Universal's assets, because the liabilities assumed by Universal exceeded the value of the assets received from Maritimecor. Id. at 212. The plaintiff alleged that two press releases issued by Maritimecor describing the transaction were materially deficient in that they failed to disclose the "conflict of interest of the principals" and that the transaction would cause Universal to incur a deficit of $\$ 3.6$ million of current liabilities. Id. at 212 \& $\mathbf{n} .2$.

14 Id. at 220-21. This theory of deception of the corporation through its independent shareholders has been termed "constructive deception." Kaplan v. Bennett, 465 F. Supp. 555, 563-66 (S.D.N.Y. 1979); Project, Recent Developments in Securities Law: Causes of Action Under Rule 10b-5, 26 Burfalo L. Rev. 503, 567-79 (1977). The Goldberg court derived the theory from the alternative holding in Schoenbaum v. Firstbrook, 405 F.2d 215, 220 (2d Cir. 1968) (en banc), cert. denied, 395 U.S. 906 (1969), see note 30 supra, which in turn relied on Pappas v. Moss, 393 F.2d 865 (3d Cir. 1968). Pappas held that where directors are all interested in a transaction, their knowledge can be imputed to the corporation, 
the court posited a hypothetical disinterested director charged with making the investment decision. Because the undisclosed facts would have been important to such a director in deciding whether to approve the transaction, the court concluded that the withheld facts were material.45 Seizing on the "negative implication"48 of footnote 14 of Santa Fe to support this finding of materiality, the court argued that the shareholders of Universal, unlike the plaintiffs in Santa Fe, were not powerless because New York law would have permitted them to seek injunctive relief to block the transaction. ${ }^{77}$ The court did not inquire whether the plaintiffs would have succeeded in such an action, although Judge Meskill argued in dissent that footnote 14 of Santa $F e$ required the derivative plaintiff to show that he would have "sought and obtained" an injunction, had full disclosure been made. ${ }^{48}$

The Second Circuit in Goldberg thus concluded that the derivative plaintiff need only demonstrate that state injunctive reme- . dies would have been available if full disclosure had been made. Four circuits have since considered the issue, however, and all have

thereby negating deception, only if full disclosure has been made to the independent shareholders. Id. at 869. Without full disclosure, the corporation ( $q u a$ independent shareholders) is deceived. This theory of constructive deception arguably is inconsistent with Santa Fe. See Virginia Note, supra note 8, at 772-74. Once full disclosure to the board of directors has been made, as it was in Goldberg, the only purpose a derivative suit could serve is to protect a minority shareholder's equity interest from unfair self-dealing. Id. at 772. "Constructive deception" simply may be another term for breach of fiduciary duty and thus outside the scope of rule 10b-5 as delineated in Santa Fe. A full treatment of this issue, however, is beyond the scope of this comment. See generally 1 A. Bromberg \& L. Lowenpels, supra note $3, \S 4.7(556)$.

ts 567 F.2d at 219.

is Kerrigan v. Merrill Lynch, Pierce, Fenner \& Smith, 450 F. Supp. 639, 644 (S.D.N.Y. 1978) (the Kerrigan court's characterization of the way the Goldberg court construed Santa $\mathrm{Fe}$ ).

47567 F.2d at 220. The Second Circuit previously had held that the availability of state injunctive relief was relevant in deciding materiality in an SEC enforcement action under rule 10b-5. SEC v. Parklane Hosiery Co., 558 F.2d 1083 (2d Cir. 1977). The court in Parklane, however, was careful to distinguish that case from a private action for damages. Thus, it is unclear whether Judge Friendly's reference to the availability of state remedies constitutes an alternate materiality holding, or merely an attempt to distinguish Santa Fe. Of course, the two interpretations amount to the same thing in that materiality was found wanting in Santa Fe. See text and note at note 38 supra. It is noteworthy, however, that in considering materiality under the Goldberg rationale, the courts of appeals have emphasized the existence of state injunctive remedies. See Healey v. Catalyst Recovery, Inc., 616 F.2d 641, 647 (3d Cir. 1980); Alabama Farm Bureau Mut. Cas. Co. v. American Fidelity Life Ins. Co., 606 F.2d 602, 613-14 (5th Cir. 1979), cert. denied, 449 U.S. 820 (1980); Kidwell ex rel. Penfold v. Meikle, 597 F.2d 1273, 1292-93 (9th Cir. 1979); Wright v. Heizer Corp., 560 F.2d 236, 250 (7th Cir. 1977), cert. denied, 434 U.S. 1066 (1978).

4867 F.2d at 223 (Meskill, J., dissenting) (emphasis added). 
held that the derivative plaintiff must make some additional showing that he would have succeeded in the state action had he not been lulled into security by the defendant's deception. ${ }^{9}{ }^{9}$ But these courts disagree about why such a showing is necessary and about how extensive the showing must be to establish liability under rule 10b-5. The standards developed by these courts range from a showing of a prima facie case for state-law relief to a showing of actual success in the state action..$^{\text {so }}$

\section{The Elements of a Rule 10b-5 Suit: Materiality, Reliance and Causation}

The conflict between the circuits over the test for when relief will be forthcoming under Goldberg is attributable in large part to their failure to analyze adequately the elements of a 10b-5 claim-materiality, reliance, and causation. If those elements are parsed correctly, it can be demonstrated that, contrary to Goldberg, rule 10b-5 should be read to require the derivative plaintiff to make some showing of success in the hypothetical state action.

Under rule 10b-5, deception by misrepresentation or omission is not sufficient by itself to establish liability; the information in question must be material. The element of materiality measures the gravity of the defendant's deception. .1 $^{\text {s1 }}$ The prevailing test of materiality was announced by the Supreme Court in TSC Industries, Inc. v. Northway, Inc.:52 an omitted or misrepresented fact is material if there is a "substantial likelihood" that it "would have assumed actual significance in the deliberations of the reasonable shareholder" or "reasonable investor." If, as in Santa Fe, the shareholder has no decision to make-that is, if the shareholder is powerless to affect the transaction-no information can be material to him. ${ }^{.3}$

19 See cases cited at notes 12-14 supra.

so See id.

${ }_{51}$ Mills v. Electric Auto-Lite Co., 396 U.S. 375, 384 (1970).

52426 U.S. 438, 449 (1976). TSC Industries was a decision under Rule 14a-9 of the federal proxy rules, but its definition of materiality was cited with approval in Santa $\mathrm{Fe}$ Indus., Inc. v. Green, 430 U.S. 462, $474 \mathrm{n.14}$ (1977), and has been deemed applicable to the securities laws in general by numerous courts of appeals. See, e.g., Steadman v. SEC, 603 F.2d 1126, 1130 (5th Cir. 1979); Goldberg v. Meridor, 567 F.2d 209, 218-19 (2d Cir. 1977), cert. denied, 434 U.S. 1069 (1978); Alton Box Board Co. v. Goldman, Sachs \& Co., 560 F.2d 916, 919-20 (8th Cir. 1977); Wright v. Heizer Corp., 560 F.2d 236, 247-48 (7th Cir. 1977), cert. denied, 434 U.S. 1066 (1978).

ss See text and note at note 38 supra. 
The concept of reliance requires the plaintiff to prove that the defendant's misrepresentation or omission of a material fact induced the plaintiff to act or refrain from acting in a certain way..$^{54}$ Proof of reliance thus involves proof that the defendant's deception actually distorted the plaintiff's decision making process. ${ }^{.5}$ In certain cases, however, the nature of the defendant's deception erects insuperable obstacles to establishing positive proof of reliance. Consequently, in Mills v. Electric Auto-Lite Co ${ }^{86}$ and Affiliated Ute Citizens of Utah $v$. United States, ${ }^{57}$ the Supreme Court relaxed the reliance requirement, permitting it to be presumed upon a finding of materiality.

Plaintiffs in Mills, shareholders in Electric Auto-Lite Company, sued as a class and derivatively under section $14 a^{58}$ and rule 14a-959 of the Securities Exchange Act to set aside a merger effectuated by a control group through materially deficient proxy solicitations. ${ }^{60}$ The plaintiffs were so numerous that the Court found it impossible to inquire into the question of reliance on the part of each individual. ${ }^{61}$ Rather, the Court held that if the defendant's misstatements or omissions were material, and the solicitation itself was an "essential link" in the transaction, there was no need to prove that the votes of any of the actual shareholders were influenced by the defendant's deception. ${ }^{62}$ This presumption of reliance was held to be irrebutable even by a showing that the transaction voted upon was fair. ${ }^{83}$

st W. Prosser, supra note $19, \S 108$.

${ }^{s 5}$ In a case involving an affirmative misrepresentation by a defendant in connection with the plaintiff's purchase or sale of securities, reliance is determined by ascertaining whether the plaintiff believed the defendant, and if so, whether that belief induced the plaintiff to enter the transaction. In a case involving a material omission, however, the question of reliance is a hypothetical one-whether the plaintiff would have acted differently if he had known the withheld fact. This question is similar to the question of materiality-whether a reasonable investor would have deemed the fact significant. R. JENNINGs \& H. MARSH, supra note 38 , at 1063-64.

se 396 U.S. 375 (1970).

37406 U.S. 128 (1972).

s8 15 U.S.C. $\S 78 \mathrm{n}(\mathrm{a})$ (1976).

s9 17 C.F.R. § 240.14a-9 (1981).

so The merger was between Electric Auto-Lite Co. and Mergenthaler Linotype Co., which controlled 54 percent of the outstanding shares of Auto-Lite. The plaintiffs claimed that the proxy statement failed to disclose that the Auto-Lite directors were controlled by Mergenthaler, and thus that their recommendation of the merger was misleading. 396 U.S. at 378 .

61 Id. at 380.
62 Id. at 385.
cs Id. at 382. 
In Affiliated Ute Citizens, Indians suing under rule $10 \mathrm{~b}-5$ alleged that bank employees purchased shares of a tribal land development company from them without disclosing the higher price at which the securities were being resold to whites in a market fostered by the bank. Again rejecting the argument that the plaintiffs had to show positive proof of reliance, the Supreme Court held that "[u $]$ nder the circumstances of this case, involving primarily a failure to disclose," reliance could be presumed from a finding that the facts withheld were material. ${ }^{\text {.4 }}$

Mills and Affiliated Ute establish that reliance may be presumed from a finding of materiality in certain types of cases where it otherwise cannot be proved that the defendant's violation distorted the plaintiff's decision making process. ${ }^{85}$ Neither case, however, abolished the requirement that the plaintiff suing under rule $10 \mathrm{~b}-5$ prove a causal connection between the defendant's violation of the rule (the misstatement or omission of material fact) and the plaintiff's injury (economic loss). ${ }^{68}$ The causation requirement is analytically distinct from the reliance requirement. Reliance tests whether there is a relation between the defendant's violation and the plaintiff's decision making process; causation, on the other hand, tests whether there is a relation between the defendant's violation and the plaintiff's injury. ${ }^{67}$ Although the two concepts are

406 U.S. at 153-54.

is Cases that present obstacles to direct proof of reliance include those involving the mass exercise of proxy rights, e.g., Kohn v. American Metal Climax, Inc. 458 F.2d 255 (3d Cir.), cert. denied, 409 U.S. 874 (1972), and those involving a failure to disclose, e.g., Titan Group Inc. v. Faggen, 513 F.2d 234, 238-39 (2d Cir.) ("in instances of . . . non-disclosure . . . it is impossible to demonstrate reliance"), cert. denied, 423 U.S. 840 (1975). See generally R. JENNINGS \& H. MARSH, supra note 38, at 1064-68.

${ }^{68}$ See Piper v. Chris-Craft Indus., Inc., 430 U.S. 1, 50-51 (Blackmun, J., concurring). See also Titan Group, Inc. v. Faggen, 513 F.2d 234, 238-39 (2d Cir.), cert. denied, 423 U.S. 840 (1975); Shapiro v. Merrill Lynch, Pierce, Fenner \& Smith Inc., 495 F.2d 228 (2d Cir. 1974).

i7 Some courts and commentators have abandoned the effort to parse causation from reliance. See text and note at note 72 infra. Instead, they simply have split causation in the context of the federal securities laws into two categories- "transaction causation" and "loss causation." See Schlick v. Penn-Dixie Cement Corp., 507 F.2d 374, 380-81 (2d Cir. 1974), cert. denied, 421 U.S. 976 (1975); 1 A. Bromberg \& L. Lowgnpels, supra note 3, § 4.7(551)(1)-(2); Note, Causation and Liability in Private Actions for Proxy Violations, 80 YALE L.J. 107, 124-25 (1970). Transaction causation is said to test whether the defendant's violation caused the transaction; loss causation is said to test whether the violation caused the injury alleged. Id. at 125 . This comment eschews the use of these catch phrases. See $R$. Jennings \& H. Marsh, supra note 38, at 1063. The elements of the common law tort action for deceit-materiality, reliance and causation-serve the same analytical purpose if used with sufficient precision. Indeed, "transaction causation" essentially is synonymous with reliance, and "Ioss causation" is synonymous with the causation requirement of rule 10b-5. 
analytically distinct, in practice proof of reliance frequently, but not always, supplies proof of the requisite causal connection.

In the typical 10b-5 case where the plaintiff makes the investment decision, proof of reliance logically compels a finding of causation. The complaint is that the defendant's misstatement or omission of fact induced the plaintiff to buy stock that was worth less than he paid for it or, as in Affiliated Ute, to sell stock that was worth more than he received. ${ }^{68}$ Because the plaintiff makes the investment decision that precipitates the injury, his injury flows directly from the distortion of his own decision making process caused by his reliance on the defendant's deception. ${ }^{69}$

Thus, in the typical 10b-5 action involving an individual investor's decision to purchase or sell securities, proof of reliance-whether positive or presumptive-establishes a fortiori proof of a causal connection between violation and injury. ${ }^{70}$ It is not surprising that courts and commentators have misread Mills and Affiliated Ute as holding that causation as well as reliance can be presumed from materiality ${ }^{71}$ and that they have used the terms reliance and causation interchangeably. ${ }^{72}$ This imprecision, however, is the source of the conflict regarding the plaintiff's required standard of proof under Goldberg. Mills and Affiliated Ute create a presumption of reliance only. Causation may be inferred from reliance only when the plaintiff makes the investment decision.

o8 R. JEnnings \& H. Marsh, supra note 38, at 1069.

${ }^{60}$ See also Chasins v. Smith, Barney \& Co., 438 F.2d 1167, 1172 (2d Cir. 1970); 1 A. Bromberg \& L. Lowenfels, supra note $3, \S 4.7(551)(2)$.

${ }^{70}$ See, e.g., 1 A. BRomberg \& L. LowENFELs, supra note 3, § 4.7(551)(2) (in direct personal deals, transaction causation is subsumed into loss causation); W. Prosser, supra note $19, \S 108$ (reliance is subsumed in the requirement of a causal connection between the wrongful conduct and the resulting damage).

71 1 A. Bromberg \& L. LowENrELs, supra note 3, § 4.7(555). The language of the Mills opinion is ambiguous. The Court stated the issue in terms of reliance: "The question with which we deal is what causal relationship must be shown between [defendant's alleged violation] and the merger." 396 U.S. at 377. It stated the holding, however, in terms of causation: "Where there has been a finding of materiality, a shareholder has made a sufficient showing of causal relationship between the violation and the injury." Id. at 385. This inconsistency in language can be viewed as a manifestation of the Court's intuitive perception that presumptive proof of reliance establishes causality where the plaintiff made the investment decision.

${ }^{72}$ See, e.g., Chasins v. Smith, Barney \& Co., 438 F.2d 1167, 1172 (2d Cir. 1970) (test of "reliance" is "causation in fact"); Globus, Inc. v. Jaroff, 266 F. Supp. 524, 530 (S.D.N.Y. 1967) (referring to the "causation requirement" rather than the "reliance requirement"); Note, The Controlling Influence Standard in Rule 10b-5 Corporate Mismanagement Cases, 86 Harv. L. REv. 1007, 1023 n.72 (1973) ("This Note will not distinguish the term "causation" from "reliance."). 
Where the plaintiff does not participate in the investment decision, as in Goldberg and its progeny, his injury results only indirectly from the defendant's violation. Although the Mills-Affiliated Ute presumption may be invoked to establish reliance in this case, causation remains a distinct element for which the plaintiff must offer independent proof.

\section{Proof of Success and Causation: The Case Law}

The most vexing question in cases premised on Goldberg is whether rule 10b-5 requires the derivative plaintiff to show that he actually would have succeeded in the state suit. All but one ${ }^{73}$ of the several courts to consider this issue have viewed it as an aspect of the materiality requirement under the federal law. ${ }^{34}$ These courts subscribe to the view that proof of success is unnecessary because, by virtue of Mills and Affiliated Ute, a finding of materiality, which triggers the presumption of reliance, disposes of any problem of causation. ${ }^{75}$ This view is implicit in the Goldberg court's holding that mere proof of the availability of a cause of action under state law-without regard to the probable outcome of such a suit-is sufficient to establish rule 10b-5 liability. Adherents to this view argue by analogy to Mills: because that case dispensed with the need to prove that enough shareholders would have changed their votes to defeat the challenged merger, there is no need in actions based on Goldberg to show that the plaintiff would have succeeded in the state suit. ${ }^{78}$

In Healey v. Catalyst Recovery of Pennsylvania, Inc. ${ }^{77}$ the Third Circuit adopted a variation of the Goldberg view. It held that a finding of "materiality," which triggers the Mills-Affiliated Ute presumption of reliance, "adequately dispose[s]" of "any problems of causation"78 under Goldberg. The Healey court stated, however, that materiality itself is dependent on some showing of

${ }^{73}$ Kidwell ex rel. Penfold v. Meikle, 597 F.2d 1273 (9th Cir. 1979). See text and notes at notes 82-90 infra.

7، See, e.g., Healey v. Catalyst Recovery, Inc., 616 F.2d 641 (3d Cir. 1980); Wright v. Heizer Corp., 560 F.2d 236 (7th Cir. 1977), cert. denied, 434 U.S. 1066 (1978); Goldberg v. Meridor, 567 F.2d 209 (2d Cir. 1977), cert. denied, 434 U.S. 1069 (1978). It is unclear what mode of analysis the Fifth Circuit used in Alabama Farm Bureau Mut. Cas. Ins. Co. v. American Fidelity Life Ins. Co., 606 F.2d 602 (5th Cir. 1979), cert. denied, 449 U.S. 820 (1980).

${ }^{75}$ See also Harvard Note, supra note 8, at 1894-95.

76 Id.

77616 F.2d 641 (3d Cir. 1980).

78 Id. at 649 . 
success in the hypothetical state action.

In Healey, a 20 percent minority shareholder brought a rule 10b-5 action against an 80 percent controlling shareholder who withheld material facts regarding a merger approved by shareholder vote. ${ }^{79}$ Although the majority had sufficient strength to approve the transaction, the court found that the plaintiff was not powerless because he could have brought suit under state law to enjoin the merger. Viewing the issue of proof of success in the state action as an aspect of the federal materiality requirement, the court declared that unless there is a reasonable probability that a shareholder could have used the withheld facts to enjoin the merger in state court, the information would not be material to the shareholder's litigation decision. ${ }^{80}$ Consequently, the court held that to establish the materiality of the defendant's deception the plaintiff must show that, at the time of the misrepresentation or omission, there was a "reasonable probability of ultimate success in securing a state injunction," if full disclosure had been made. ${ }^{81}$

In Kidwell ex rel. Penfold v. Meikle, ${ }^{82}$ the Ninth Circuit rejected Goldberg and Healey and viewed the issue of success in the hypothetical state action as an aspect of rule 10b-5's causation requirement. In Kidwell, minority shareholders in an Idaho nonprofit corporation brought a derivative $10 \mathrm{~b}-5$ action against the corporation's directors, who had voted to sell its assets to a Wyoming concern. The court found deception in the defendant-directors' failure to disclose certain conflicts of interest. ${ }^{83}$ Although shareholder approval of the transaction was not necessary because the corporation was insolvent, Idaho law would have permitted the derivative shareholders to bring suit to enjoin the sale. ${ }^{84}$ In determining whether the nondisclosures were material, Kidwell explicitly disapproved the Goldberg materiality test, which focuses on the importance of the information to an imaginary disinterested director. ${ }^{85}$ The court also rejected the view stated by the Third

79 Because the plaintiff in Healey was not suing derivatively, his action did not depend on deception of the corporation.

so 616 F.2d at 647 .

81 Id.

s2 597 F.2d 1273 (9th Cir. 1979).

s3 The plaintiffs alleged that the defendants had failed to disclose that some directors of the nonprofit corporation were shareholders in a for-profit "sister corporation," that some directors had assumed personal liability for corporate debts, and that one director may have acted as legal counsel to both the nonprofit and for-profit corporations. Id. at 1282-85, 1293.

st Id. at 1293.

ss Id. at 1293 n.10. See text and note at note 45 supra. 
Circuit in Healey, that materiality is dependent on some showing of success in the state action. Instead, the Ninth Circuit focused on the shareholder's litigation decision and found the withheld facts to be material "[s]ince a reasonable minority shareholder probably would have considered this information important in any decision whether or not to sue to block the sale."

The court observed that under Mills and Affiliated Ute, such a finding of materiality creates a presumption of reliance-that the defendant's violation induced the minority shareholders to refrain from filing suit in state court to block the sale. ${ }^{87}$ The court, however, asserted that this presumption of reliance "does not dispose of the entire element of causation in the Rule 10b-5 suit. . . . The mere fact that a minority . . . [shareholder] may have been able to state a claim in a suit under state law to block the sale does not mean that he or she would have been successful." cuit thus viewed the issue of success in the state suit as an aspect of the causation requirement. Because only the reality or credible threat of obtaining a state injunction would have deterred the corporate fiduciaries from completing the transaction, proof of a causal relation between violation and injury required some showing that the state action would have been successful. The Kidwell court consequently held that the plaintiff must show that he "would have succeeded in getting permanent injunctive relief, or damages in excess of an appraisal remedy, in the state-law action." 89 Contemplating a complete trial of the state claim, Kidwell declared that whether the state suit would have succeeded was primarily a question of fact for the jury, but directed the federal trial court to "decide any legal issues that would have arisen in the hypothetical state suit as a matter of law in the Rule 10b-5 suit."

\section{The Proper Test for Liability}

Only Kidwell developed a standard of proof that recognizes the distinction between the litigation decision central to Goldberg and its progeny, and the investment decision characteristic of other 10b-5 suits. The court in Kidwell correctly formulated the materiality test in terms of this litigation decision. More impor-

so 597 F.2d at 1293.

87 Id. at 1293-94.

sos. at 1294.

so Id.

${ }^{\circ}$ Id. 
tantly, it recognized that where the investment decision that causes the injury is not made by the plaintiff, proof of reliance fails to establish automatically a causal connection between defendant's violation and plaintiff's injury. The Kidwell requirement of demonstrating complete success in the hypothetical state action, however, conflicts with principles of federalism, which limit the showing of success a federal court may require the $10 \mathrm{~b}-5$ plaintiff to make.

\section{A. Materiality}

According to TSC Industries, Inc. v. Northway, Inc., ${ }^{91}$ the materiality of a misrepresented or omitted fact depends on its "significance" to the decision making process of a "reasonable investor." Because in the case of corporate mismanagement the corporation itself is the investor, the Goldberg court phrased the materiality inquiry in terms of the importance of the information to an imaginary disinterested director charged with making the investment decision. ${ }^{83}$ The court was misguided, however, in attempting to make the corporate mismanagement case conform to the investment decision paradigm by invoking the services of an imaginary director. Where a majority or all of the directors are interested in the transaction, the independent shareholder is the only party capable of protecting the corporation's interests by filing an injunctive action under state law. If injunctive relief is unavailable, no misrepresentation or omission, however egregious, can be deemed material. Having implied a rule $10 \mathrm{~b}-5$ cause of action because state injunctive remedies exist, Goldberg logically should have phrased the materiality inquiry, as did Kidwell, with reference to an actual shareholder capable of resorting to such remedies. ${ }^{94}$

If the proper subject of the materiality inquiry is the shareholder, the next question is what information would be material to his deliberations. The Third Circuit in Healey stated that a withheld fact is significant only if there is a reasonable probability that a shareholder could have used it to obtain state relief. ${ }^{25}$ This test controverts the Supreme Court's admonition in TSC Industries to

\footnotetext{
21 426 U.S. 438 (1976).

${ }^{92}$ Id. at 449. See text and notes at notes 51-53 supra.

8s 567 F.2d at 219 .

2 See Sherrard, supra note 26 , at 712 .

ss 616 F.2d at 647 .
} 
test the materiality of facts by their significance to the deliberations of the reasonable shareholder, not by their significance to the probable outcome of those deliberations. Moreover, the Healey test fails to consider that a plaintiff may file a state action on information and belief. ${ }^{96}$ Consequently, in certain cases, such as vexatious suits, the decision to file may be wholly unrelated to the probability of success on the merits. In other cases, the information withheld may not evince a reasonable probability of success, but may be sufficiently suggestive to warrant the filing of a suit and the pursuit of further facts through discovery. Thus, the materiality of facts must be judged, as it 'was in Kidwell, solely with reference to their significance to the shareholder's decision to seek state relief, not their significance to the probability of obtaining such relief. The latter inquiry is relevant only to the element of causation.

\section{B. The Necessity of Demonstrating Causation}

In cases premised on Goldberg, a finding of materiality should not be viewed as automatically establishing a causal connection between the defendant's violation and the plaintiff's injury. Mills and Affiliated Ute establish that in certain cases proof of materiality creates a presumption of reliance. When the plaintiff is the investment decision maker, a causal connection between violation and injury can be inferred automatically from such a presumption. In Goldberg and its progeny, however, the plaintiff is presented with a litigation decision rather than an investment decision. ${ }^{97}$ Consequently, a presumption of reliance does not operate to establish causation: even if it is presumed that the defendant's violation lulled the plaintiff into refraining from filing a state suit, it does not follow a fortiori that that violation caused the plaintiff's injury. Rather, the defendant's violation can be said to have caused the plaintiff's injury only if the state suit would have succeeded in deterring the defendant-insiders from the purchase or sale of securities that led to that injury. Thus, the existence of the state suit in cases like Goldberg so attenuates the relationship between violation and injury ${ }^{98}$ that some showing that the plaintiff would have

96 Id. at 651 (Aldisert, J., dissenting).

97 See text and notes at notes 26-31 supra.

83 The relationship between violation and injury is even more attenuated in cases arising in states where injunctive relief for breach of fiduciary duty is available only through the offices of the state attorney general. See, e.g., People v. Concord Fabrics, Inc., 83 Misc. 2d 
succeeded in the state action is essential to establish the requisite causal connection.99

Moreover, the presumption of Mills and Affliated Ute is invoked properly only in cases that present inherent obstacles to direct proof of reliance. Thus in Mills, a class action, it was presumed that a sufficient number of shareholders would have changed their votes to defeat the transaction because it was impossible to inquire into reliance on the part of thousands of individuals. ${ }^{100}$ Similar obstacles to proof do not exist in cases like Goldberg. Because federal courts frequently rule on questions of state law, the federal trial court is competent to determine whether the hypothetical state action would have been successful. Consequently, the Mills-Affiliated Ute presumption should not relieve the derivative plaintiff of the burden of showing success in the hypothetical state action.

\section{Limitations on the Degree of Proof Required}

Although some showing of success in the hypothetical state suit should be necessary to establish causation in a rule $10 \mathrm{~b}-5$ claim premised on Goldberg, competing federal and state interests

120, 371 N.Y.S.2d 550 (Sup. Ct.), aff'd, 50 A.D.2d 787, 377 N.Y.S.2d 84 (1975). In such a case, materiality must be judged with respect to the shareholder's decision to file a complaint with the state attorney general. If materiality is established, Mills and Affiliated Ute permit a presumption that the shareholder in fact would have filed a complaint. It would strain logic, however, to argue that such a presumption automatically establishes causation-that is, that the attorney general subsequently would have filed a state action, that the action would have succeeded, and that the plaintiff's injury thus would have been averted.

op Justice Blackmun, the author of Affiliated Ute, employed similar reasoning in his concurring opinion in Piper v. Chris-Craft Indus., Inc., 430 U.S. 1, 48 (1977). He argued that in a suit by a defeated tender offeror to recover damages as a result of securities law violations by its competitor, the Mills-Affiliated Ute presumption suffices to establish reliance-that is, that the competitor's violations induced the shareholders of the target company to tender to it. Id. at 51. According to Justice Blackmun, however, this presumption of reliance does not also establish causation-that the competitor's violations caused the plaintiff to lose the contest for control. Rather, he argued that the disappointed offeror still must present some evidence that the competitor's material misstatements or omissions caused the injury of which the offeror complains: "[T] he absence of any evidence that the violations might have altered the outcome of the contest for control would leave me unable to hold that the securities law violations caused the disappointed contestant's ultimate injury-its failure to acquire control of the target corporation." Id. at 51. Similarly, in Goldberg and its progeny, the Mills-Affiliated Ute presumption may suffice to prove that the defendant-insider's violation caused the derivative plaintiff to refrain from filing a state injunctive action, but the plaintiff still should show a causal connection between the violation and the injury alleged.

${ }^{200}$ See text and notes at notes 58-63 supra. 
circumscribe the showing that a federal court may require the plaintiff to make. The federal interest in preventing vexatious litigation favors Kidwell's standard of a showing of complete success. The states' interest in the unimpeded development of their corporation law, however, militates against so rigorous a standard because it compels a complete trial of the state claim in federal court.

The Supreme Court has expressed on numerous occasions a desire to avoid frivolous suits and vexatious litigation from a widely expanded class of plaintiffs under rule 10b-5. ${ }^{101}$ The Court has observed that even an unmeritorious $10 \mathrm{~b}-5$ claim has an in terrorem settlement value, ${ }^{102}$ and a desire to avoid such suits was cited by the Court as a reason for dismissing the plaintiff's action in Santa Fe. ${ }^{103}$ If, as has been argued, ${ }^{104}$ the Goldberg court's implication of a 10b-5 cause of action in favor of the "reasonable litigant," as opposed to the "reasonable investor," reopens the doors of federal courts to matters Santa Fe intended to relegate to state courts, then permitting a plaintiff to establish rule 10b-5 liability under Goldberg without some showing of success in the state action would only further eviscerate Santa Fe. Absent a requirement for such a showing, it would be impossible for federal courts to discriminate between bona fide and frivolous 10b-5 claims.

The Court's emphasis on federalism in Santa Fe, however, militates against adoption of the Kidwell standard. Part IV of Santa $\mathrm{Fe}$ constitutes a direction to the federal judiciary that the federal securities laws should not be expanded to usurp or interfere with state corporation law; ${ }^{105}$ some federal courts accordingly have refused to construe state law on the grounds that such an inquiry would contravene Santa $\mathrm{Fe}^{108}$ Yet in evaluating whether

101 See Santa Fe Indus., Inc. v. Green, 430 U.S. 462, 479 (1977); Ernst \& Ernst v. Hochfelder, 425 U.S. 185, 214 n.33 (1976); Blue Chip Stamps v. Manor Drug Stores, 421 U.S. 723, 742 (1975). See generally Lowenfels, supra note 4.

${ }^{102}$ Blue Chip Stamps v. Manor Drug Stores, 421 U.S. 723, 742 (1975).

103430 U.S. at $478-79$.

${ }^{104}$ Virginia Note, supra note 8 , at 765. See also note 10 supra.

108430 U.S. at 478. See text and notes at notes 39-41 supra.

${ }^{106}$ See, e.g., Kerrigan v. Merrill Lynch, Pierce, Fenner \& Smith, Inc., 450 F. Supp. 639 (S.D.N.Y. 1978). Kerrigan involved a corporation's exercise of an option to repurchase stock from employees without disclosing that the corporation planned to go public. The plaintiffs' materiality theory was that had they known the true facts, they would have resisted the transaction by asking the state court to make new law holding the challenged transaction discriminatory under state fiduciary standards. The federal court rejected this argument, stating that "rule 10b-5 was not designed to serve as a federal vehicle for raising pure state law questions. If this were permitted, federal courts would be required to speculate on new questions of state corporation law in order to determine only one element of the federal $10 \mathrm{~b}$ - 
the derivative plaintiff's state suit actually would have been successful, federal courts would be compelled to determine the fairness of the transaction under state law. Although Santa Fe rejected only the imposition of a federal fairness standard, a federal court's interpretation of a state fairness standard has potential for substantial interference with the development of state corporation law. ${ }^{107}$ Kidwell reasoned that such interference can be minimized only by a complete trial in federal court of the hypothetical state claim. ${ }^{108}$ In that trial the federal court would be compelled to apply exactly the same fairness standard that would have been applied by the state court. This test, however, proves too much. The federal purpose under rule $10 \mathrm{~b}-5$ is to ensure full disclosure and to redress deception. The hypothetical state action is relevant only for purposes of establishing the materiality of the alleged deception and its causal relation to the plaintiff's injury. A standard of actual success goes beyond the limited federal purpose to afford minority shareholders "the same right they would have had if full disclosure had been made, i.e., the right to obtain a judicial determination of the fairness of a transaction" under state law. ${ }^{109}$ Such a determination is interdicted by part IV of Santa Fe, which ruled that fairness was but a subsidiary purpose of the Securities Exchange Act.

\section{A Prima Facie Standard of Causation}

The appropriate showing of success in the state action must lie somewhere between the extremes of Goldberg and Kidwell.10 That standard was set forth by the Fifth Circuit in Alabama Farm Bureau Mutual Casualty Co. v. American Fidelity Life Insurance Co., ${ }^{111}$ where the court required the derivative plaintiff to show that he would have had a prima facie case for state injunctive relief. The case was a derivative action in which a minority share-

5 claim." Id. at 646. See also Voege v. Magnavox Co., 439 F. Supp. 935, 942 (D. Del. 1977) (declining to construe state law to determine if an attorney's opinion in a proxy statement was correct, because to do so would disregard "the restrictive philosophy expressed in Part IV of the Santa Fe decision").

107 See Harvard Note, supra note 8, at 1895.

108597 F.2d at 1294.

${ }^{103}$ Wright v. Heizer Corp., 560 F.2d 236, 250 (7th Cir. 1977), cert. denied, 434 U.S. 1066 (1978).

${ }_{110}$ But compare Harvard Note, supra note 8, at 1895-98 (arguing that the Goldberg standard is correct) with Richmond Note, supra note 14, at 601-03 (arguing that the Kidwell standard is the appropriate measure of proof).

${ }^{111} 606$ F.2d 602 (5th Cir. 1979), cert. denied, 449 U.S. 820 (1980). 
holder charged that corporate directors had violated rules $10 \mathrm{~b}-5$ and 14a-9 by causing the corporation to launch a stock repurchase program to perpetuate their control, without disclosing the inflationary effect the repurchase plan would have on the price of the outstanding stock. ${ }^{112}$ The court held that to establish rule $10 \mathrm{~b}-5$ liability, a derivative plaintiff must show that "state law remedies were available and that the facts shown make out a prima facie case for relief; it is not necessary to go further and prove that the state action would have been successful."113 The court reasoned that to permit recovery merely because state law remedies existed, as Goldberg did, was to predicate federal relief on a hypothetical basis, but that to permit recovery only upon proof of victory, as Kidwell did, effectively would require the equivalent of a trial of the state claim in federal court.

The standard of proof developed in Alabama Farm is rigorous enough to effectuate the federal interest in promoting full disclosure while avoiding vexatious suits, yet liberal enough to protect the traditional state interest in the development of corporation law. The prima facie standard requires the plaintiff to produce sufficient evidence on the state claim to survive a directed verdict or motion to dismiss, thus shifting the burden of nonpersuasion to the defendant. ${ }^{114}$ Although such a showing does not establish with certainty that the plaintiff would have secured a state injunction, it does establish that he would have presented a credible threat of deterring the challenged transaction. ${ }^{115}$

112 The derivative plaintiff, Alabama Farm, had acquired its 20 percent share of defendant American Fidelity as part of a plan to obtain control of American Fidelity. This fact led Judge Skelton to dissent partly on the ground that Alabama Farm had brought a vexatious suit to gain through litigation the control it had failed to acquire in the marketplace. Id. at 618 n.1.

11 Id. at 614 .

${ }_{116}$ There are two senses in which courts use the concept of a prima facie case, and it is often difficult, as with the Fifth Circuit's decision, to determine which a court intends to apply. $9 \mathrm{~J}$. Wigmore, EvmENCE $\S 2494$ (3d ed. 1940). The term often is used in the sense of the plaintiff producing evidence sufficient to survive a motion for a directed verdict or a motion to dismiss. This "sufficiency of the evidence" test frequently is referred to as a "prima facie case." Id. Courts also use "prima facie" to indicate that the plaintiff, who bears the risk of nonpersuasion before the jury, not only has produced evidence sufficient to get past the judge to the jury, but has shifted the risk of nonpersuasion to the defendant. Id. See also White v. Abrams, 495 F.2d 724, 729 (9th Cir. 1974).

The court in Alabama Farm failed to define what it meant by a "prima facie case." The second, stricter definition is the one that should be used: it best achieves the dual purpose of establishing causation and preserving state-federal comity.

118 That proof of something less than absolute success is sufficient to establish the requisite causal connection is implicit in Justice Blackmun's concurring opinion in Piper v. 
The prima facie standard also avoids the necessity of a complete trial of the state claim in federal court. Because the existence of a prima facie case can be determined as a matter of law by the court, the potential for federal interference with state corporation law is minimized. Unlike the Ninth Circuit's actual success standard ${ }^{116}$ and the Third Circuit's "reasonable probability of ultimate success" standard, ${ }^{117}$ the prima facie standard avoids burdening the federal jury with the difficult task of testing the relevant facts against the applicable state law to determine the outcome of the hypothetical state suit. ${ }^{118}$ Finally, as evidenced by Goldberg itself, most rule $10 \mathrm{~b}-5$ actions arise on a motion to dismiss or on a motion for summary judgment. The procedural posture of these cases is such that the plaintiff has yet to develop sufficient evidence to establish conclusively that a state court action would have been successful; therefore, only the prima facie standard is suitable for the typical case in which a causation test must be applied.

The prima facie standard developed by the Fifth Circuit is both conceptually sound and administratively practical. It must be recognized, however, that such a standard represents a compromise between the federal interest in ensuring a free market in securities transactions, and the traditional state interest in the regulation of corporate affairs. ${ }^{119}$ Indeed, the disparate tests for determining the availability of $10 \mathrm{~b}-5$ relief in cases like Goldberg demonstrate the difficulty federal courts are having, and will continue to have, with expansively construing the federal securities laws while attempting to avoid conflicts with state corporation law. The prima facie standard does not eliminate the potential for state-federal conflict inherent in the Goldberg regimen of recognizing a federal cause of action only where state remedies are available. The standard does,

Chris-Craft Indus., Inc., 430 U.S. 1, 48 (1977). Blackmun would have denied Chris-Craft federal relief because there was an "absence of any evidence that the violations" caused the injury of which Chris-Craft complained. Id. at 51 (emphasis added).

${ }^{118}$ Kidwell ex rel. Penfold v. Meikle, 597 F.2d 1273, 1294 (9th Cir. 1979).

${ }_{117}$ Healey v. Catalyst Recovery, Inc., 616 F.2d 641, 648 (3d Cir. 1980).

118 This is a virtue particularly in cases involving multinational securities transactions, where the applicable "state law" may be the law of a foreign country. See, e.g., IIT v. Cornfeld, 462 F. Supp. 209 (S.D.N.Y. 1978) (plaintiffs argued that they would have been able to establish a claim for an injunction under the law of Luxembourg, if full disclosure had been made), aff'd in part, rev'd in part, and remanded, $619 \mathrm{~F} .2 \mathrm{~d} 909$ (2d Cir. 1980). In such a case, the legal determination of a prima facie case by the federal court is difficult enough; a jury determination of absolute success would be virtually impossible.

119 See Healey v. Catalyst Recovery, Inc., 616 F.2d 641, 660 (3d Cir. 1980) (Aldisert, J., dissenting). 
however, minimize federal encroachment on the state scheme of corporate regulation.

\section{CONCLUSION}

This comment has advocated that the issue of the plaintiff's standard of proof under Goldberg be resolved in favor of requiring the derivative plaintiff to make out a prima facie case for entitlement to state court relief. In cases like Goldberg, as opposed to the typical rule $10 \mathrm{~b}-5$ case, the plaintiff is presented with a litigation decision, not an investment decision. Consequently, a causal connection between the defendant's violation of the rule and the plaintiff's injury cannot be inferred automatically from proof of the parallel elements of materiality and reliance. Some showing that the plaintiff would have succeeded in the hypothetical state action is necessary to establish the requisite causal connection. Demonstration of a prima facie case for state relief is sufficient for the imposition of $10 \mathrm{~b}-5$ liability. The prima facie standard is rigorous enough to establish causation, thus preventing vexatious litigation, yet liberal enough to avoid a trial of the state claim in federal court, thus minimizing federal interference with state corporation law.

Gary R. Edson 